\title{
Video Conference: Strategy Collaboration Counselor and Parents in New Normal Era
}

\author{
Dwi Putranti ${ }^{1}$, Caraka Putra Bhakti ${ }^{2}$, Fuad Aminur Rahman ${ }^{3}$, Cucu Kurniasih ${ }^{4}$ \\ ${ }^{1,2,4}$ Ahmad Dahlan University, Yogyakarta, Indonesia, ${ }^{3}$ SMAN 1 Cihara Lebak Regency, Indonesia \\ *dwi.putranti@bk.uad.ac.id
}

\begin{abstract}
This study aims to discuss the use of video conferencing as a medium in collaboration strategies between parents and counselors in the new normal era. Namely how the counselor is able to use video conference media to collaborate with parents of students, especially in the new normal era, which is an era that focuses on changing traditional patterns or old lifestyles towards new patterns or normal lifestyles for individuals or groups in carrying out life, the new normal era. or the adaptation of new habits is the impact of the spread of the COVID-19 pandemic outbreak. Therefore, it is hoped that this research will be able to provide an overview or direction for counselors in using video conferencing as a collaboration medium with parents in the new normal era.
\end{abstract}

Keywords: video conference; collaboration; new normal era

\section{Introduction}

Collaboration is a general term that is often used to describe a pattern of cooperative relations carried out by more than one party. There are various definitions of collaboration put forward by various experts with various viewpoints. These various definitions are based on the same principles, namely regarding togetherness, cooperation, sharing of duties, equality, responsibility and accountability. However, it is not easy to define the concept of collaboration completely and completely.

In general, collaboration is a relationship between organizations that participate and agree with each other to jointly achieve goals, share information, share resources, share benefits, and take responsibility for joint decision-making to solve various problems. Meanwhile, collaboration in guidance and counseling is how the counselor is able to collaborate with various stakeholders or personal who are able to support the achievement of the goals of guidance and counseling in schools as well as parents [1].

Collaboration is not limited by a certain time or period, as long as there are matters that have offenses or intersections with other parties, collaboration is still needed. Collaboration involving several parties starting from the individual, working group and organizational levels. In carrying out collaboration, it is very important to understand the performance of public institutions. Therefore, collaborative studies focus more on the organizational level of the organization public sector. [2]. So collaboration is a joint effort between one party and another to achieve common goals and agreements.

At the institutional level as well as schools an integral feature of the success of professional development programs is active collaboration among teachers. For example, 
program professional development that is part of the whole school reform effort is designed to encourage collaboration among teachers in schools, both with parents and related parties so that they coordinate instructions to achieve common goals [3].

Due to the spread of the Covid-19 pandemic outbreak that is happening in the world today, the collaboration process that must be carried out by guidance and counseling teachers or counselors in schools needs to be done virtually or online. Based on data compiled from Worldometers website data, until Sunday (23/8/2020) morning, the total confirmed cases of Covid-19 in the world were 23,357,435 (23.3 million) cases. Of these, 15,849,720 (15.8 million) patients have recovered, and 807,677 people have died. Currently, there are 6,700,038 active cases, with details of 6,638,209 patients with mild conditions and 61,829 in serious conditions. [4].

Based on the above, the world is currently entering a new normal era or an era of adaptation to new habits, namely the era that was launched from the Lexico 2020 site, one of the sites on Oxford's observation explains that the new normal is a condition previously unusual by humans which is then used as a standard in life processes, expectations or habits that must be carried out. A small example is humans 'forcibly' asked to switch to work and study through the network, or carry out activities with health protocols and other activities that are based online [5]. So the new normal era is an era that has an impact on changes in every line of human life, such as changes in life systems, health, and activities that begin to switch online.

Information technology brings complexity to a virtual reality that breaks the deadlock that real life has regarding the concept of space and time. Virtual reality allows people who are at different places and times to communicate directly using internet media [6]. Therefore, based on the above data, there is a need for strategies or alternatives in helping guidance and counseling teachers to collaborate with parents, one of which is through video conference media, namely is an effective means of telecommunications between two or more people, anywhere in the world.

By using this service, one can not only talk to each other but can even view videos of the people they interact with. It is an effective two-way communication of audio and video transmission. This service makes use of the internet for data transmission [7].

Therefore, the explanation above makes the development of a parent collaboration strategy with counselors through video conferences a must, especially in the new normal era. Based on research from Sama, H, 2014 states that video conferencing is declared to be effective and efficient in its use such as employee recruitment and the use of video conference media which is more flexible in its use [8]. Also, the use of video conferencing as interactive learning media shows its practicality and effectiveness [9]

\section{Methodology}

This research will use descriptive qualitative research with study literature methode. Descriptive research is conducted to describe the truth about a variable that is not yet clear by collecting collected data and analyzing conclusions systematically and accurately. The instrument used was a documentation study. Researchers document books, journals, proceedings, or related documents about video conferences and also parents' collaborative strategies with concerts. The function of documents as a data source is a concept development in literature study research 


\section{A. Essence of Collaboration}

Collaboration is a form of social interaction process in achieving certain goals. Collaboration is also a form of social process, in which there are certain activities aimed at achieving common goals by helping and understanding each other's activities. [10]. It can also be said to be an effort to achieve common goals that have been determined through the division of tasks / jobs, not as a division of work but as a unit of work, all of which are directed at achieving goals [11].

Meanwhile, it is said that in guidance and counseling, the guidance and counseling program is a form of collaborative benefit for students, parents, teachers, administrative staff, and all levels of society. Collaboration in the perspective of guidance and counseling is a collaborative activity between guidance and counseling teachers/school counselors and several related parties such as parents, educators and other education personnel with the aim that the objectives of the guidance and counseling program can be achieved properly. [12].

Although school counselors have major responsibilities in this develop comprehensive programs, but they cannot meet this global challenge without the help and support of other professionals, the school system, and the communitys [13]. Thus, school counselors must systematically initiate peer relationships with various educational experts and medical services that provide additional services to the population or students in schools. [14].

To achieve goals in the educational process such as guidance and counseling, teachers have tried to organize various types of collaborative activities in their classroom teaching. This is especially important for a counseling teacher because understanding the possible causes of ineffective collaboration can help the teacher to implement fun and successful collaboration strategies. [15].

Therefore, a teacher or educator needs to be aware of the need to be involved in collaboration, especially when at school with leaders, colleagues and parents. [16]. Collaboration is also a strategy that has the potential to improve educational competence or a teacher in carrying out educational process activities in schools [17]

The following are the values that need to be understood by a counseling teacher in implementing collaborative activities with any party, especially with parents

Table 1. The Values of Collaboration

\begin{tabular}{|c|c|c|}
\hline No & $\begin{array}{l}\text { The Values of } \\
\text { Collaboration }\end{array}$ & Description \\
\hline 1 & $\begin{array}{l}\text { Respect for } \\
\text { People }\end{array}$ & $\begin{array}{l}\text { BK teachers need to have mutual respect and respect when the } \\
\text { collaborative process is carried out, this is so that each role has } \\
\text { a strong position and equality }\end{array}$ \\
\hline 2 & $\begin{array}{l}\text { Honor and } \\
\text { Integrity }\end{array}$ & $\begin{array}{l}\text { Respect and integrity give recognition, work ethic } \\
\text { (Honor and integrity). In many cultures, honor and } \\
\text { integrity shapes individual behavior. }\end{array}$ \\
\hline 3 & $\begin{array}{l}\text { Ownership and } \\
\text { Alignment }\end{array}$ & $\begin{array}{l}\text { When all employees feel they own their workplace, job and } \\
\text { company then they will take good care of it. }\end{array}$ \\
\hline 4 & Consensus & $\begin{array}{l}\text { It is general agreement that immense utility is a working } \\
\text { relationship based on the desire to win-win (win-win amounts } \\
\text { to). }\end{array}$ \\
\hline 5 & $\begin{array}{l}\text { Full } \\
\text { Responsibility } \\
\text { and } \\
\text { Accountability }\end{array}$ & $\begin{array}{l}\text { In the hierarchy paradigm usually people become closed to one } \\
\text { another, because of the job description, because of his duties } \\
\text { and because organizational unit. In fact everyone will only } \\
\text { responsible for the list of job duties only }\end{array}$ \\
\hline 6 & Trust-based & There needs to be mutual trust, because mutual trust is the key \\
\hline
\end{tabular}




\begin{tabular}{|c|c|c|}
\hline No & $\begin{array}{l}\text { The Values of } \\
\text { Collaboration }\end{array}$ & Description \\
\hline & Relationship & $\begin{array}{l}\text { to the success of counseling teachers in collaborating with } \\
\text { related parties }\end{array}$ \\
\hline 7 & $\begin{array}{l}\text { Recognition } \\
\text { and Growth }\end{array}$ & $\begin{array}{l}\text { It is no less important in a collaborative workplace is an effort } \\
\text { to encourage people to want to work, and immediately give } \\
\text { recognition to the work of someone for all members of the } \\
\text { team or group }\end{array}$ \\
\hline
\end{tabular}

[18] Noorsyamsa Djumara, op. cit., pp. 36-38. 2009

The table above explains the values that must be understood and mastered in carrying out collaborative activities by every educator, especially counseling teachers with parents of students, one of which is by giving mutual respect and respect first and strong support for each other, so that if this happens will make it easier for educators, namely BK teachers in achieving the objectives of BK services in schools.

In order to be successful in carrying out collaboration, then it takes basic generally accepted principles. This matter as explained by Edralin and Whitaker (Keban) who said that the generally accepted basic principles as the basic principles in the concept of good governance, namely: 1). Transparency, 2). Accountability, 3). Participation, 4). Efficiency, 5). Effectiveness, 6). Consensus, and 7). Mutual benefit and advance [19]

The explanation above explains that there needs to be an implication of the values and principles of collaboration that need to be understood and carried out by a counseling teacher, especially when collaborating with parents of students. Of course the use of these collaboration values and principles is an indicator of the success of collaboration carried out by BK teachers as in the new normal era this time.So the process will be more meaningful.

In an organizational perspective, such as educational institutions or groups, the conflict problem that occurs is a behavioral shift. Conflict resolution from an organizational perspective can be resolved through five approaches, one of which is collaboration. The five approaches are shown in the following figure [20] :

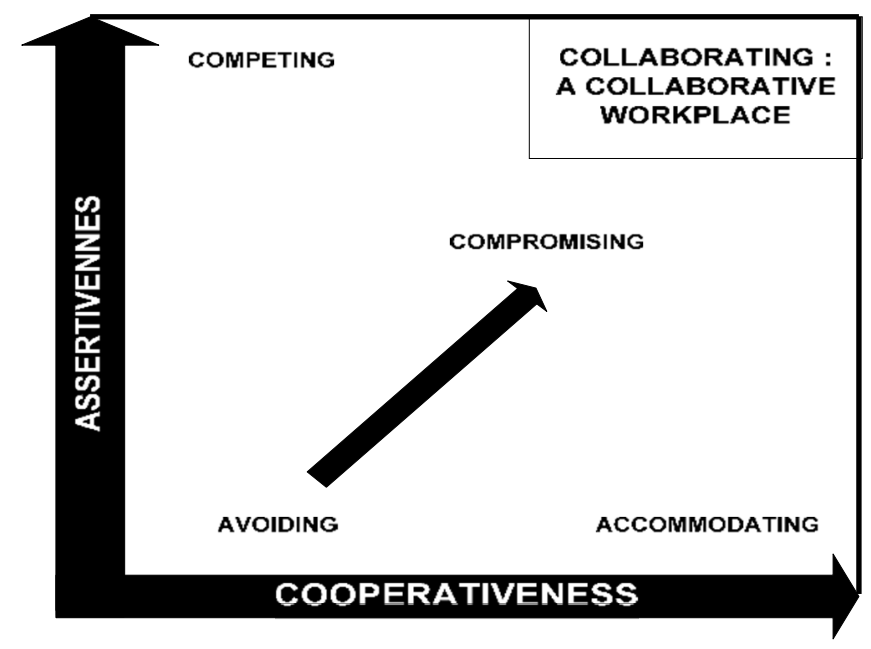

Marshal, Transforming the Way We Work; The Power of Collaborative Workplace, pp.40, (2010

Figure 1. Collaboration as a Form of Conflict Management 
The elaboration of the form of conflict resolution is further explained [21] Competition, namely actions to satisfy their interests without considering the other party because other parties are deemed to be doing the same thing. Collaboration, namely actions taken by conflicting parties to produce actions that satisfy all parties as "win-win" actions. Avoiding, namely actions to "avoid" in the sense of ignoring the conflict on the basis that the opposing party does not have significant power, Accommodation, which is an action to relieve pressure from other parties by putting the interests of others first. Compromise, namely collective action that is a middle way, without satisfying all parties because each party makes sacrifices to meet the satisfaction of the other party.

\section{B. Concept of Video Conference}

Video conferencing is a communication technology that allows the occurrence of communication from several different locations simultaneously can simultaneously transmit video images and sound. To conduct a video conference, you can take advantage of IP network technology (via the internet) and ISDN technology (Integrated Services Digital Network). Although video conferencing has the advantage of having a visual display (video), the use of this teleconferencing facility is still less popular in Indonesia due to the following reasons:

It takes a special device such as a video input (video camera or webcam) and video output (monitor), audio input (microphone) and audio output (speaker) as well as data transfer facilities (telephone network) ISDN, LAN or Internet)

Relatively expensive costs Currently, video conferencing is more widely used by television media and large-scale companies [22].

Video conferencing can also be said to be an interactive telecommunication technology device that allows two or more parties in different locations to interact by sending two-way audio and video simultaneously, and one party can make a presentation and can be seen by each party, and vice versa [23]. video conferencing is a great concept of modern communication, because take advantage of technological developments with the supporting devices [24].

Video conferencing must be supported by three devices or components in the form of hardware such as computers or hardware video recorder, internet network and video conference room [25]. Based on the above, it can be concluded that video conferencing is a set of modern technological tools, which require support from software or other hardware and internet networks in its implementation, with the aim of building communication, coordination or activities between one party and another, carried out in real time though with a different location.

The following is an overview of the configuration system rather than the use of video conferencing as a medium for carrying out an activity between one party and another

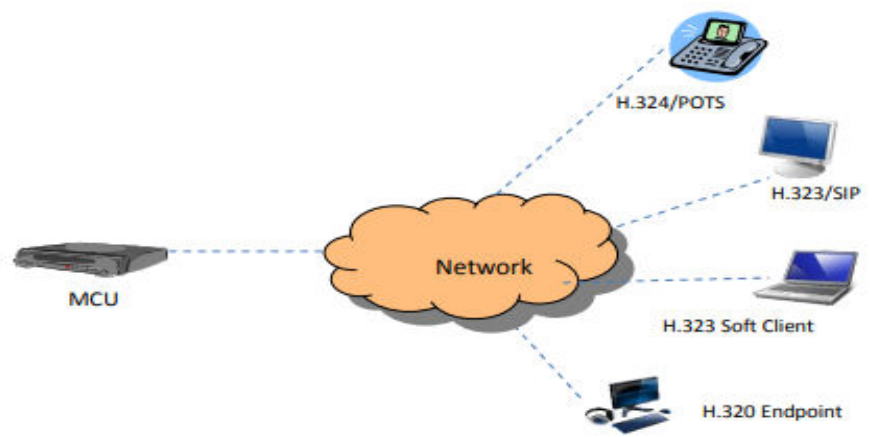

Kementrian Komunikasi dan Informatika Republik Indonesia, pp 1, (2013)

Figure 2. Video Conference Configuration System 
Video conferencing is synchronous audio-visual communication. Video conferencing first appeared in the 1960s and is widely used in the business sector, it is considered by business people to be more effective and efficient in both time and cost [26]. Video conferences in the world of education can be used in collaborative activities between classes, presenting virtual experts, distance learning, and used for teacher-teacher meetings [27]

\section{Discussion}

\section{Implementation Video Conference as Strategy Collaboration Counselor and Parents In} New Normal Era

Video conferencing as a supporting medium in the learning process has been widely used among educators and students to build effective communication between teachers and students or their peers. This media is used when face-to-face activities may not be possible [28]. Video conferencing is a part of visual and virtual communication between two or more users who have different locations as well as display live transmission of audio and video content [29]. The following is an illustration of various alternative collaboration strategies in utilizing video conference:

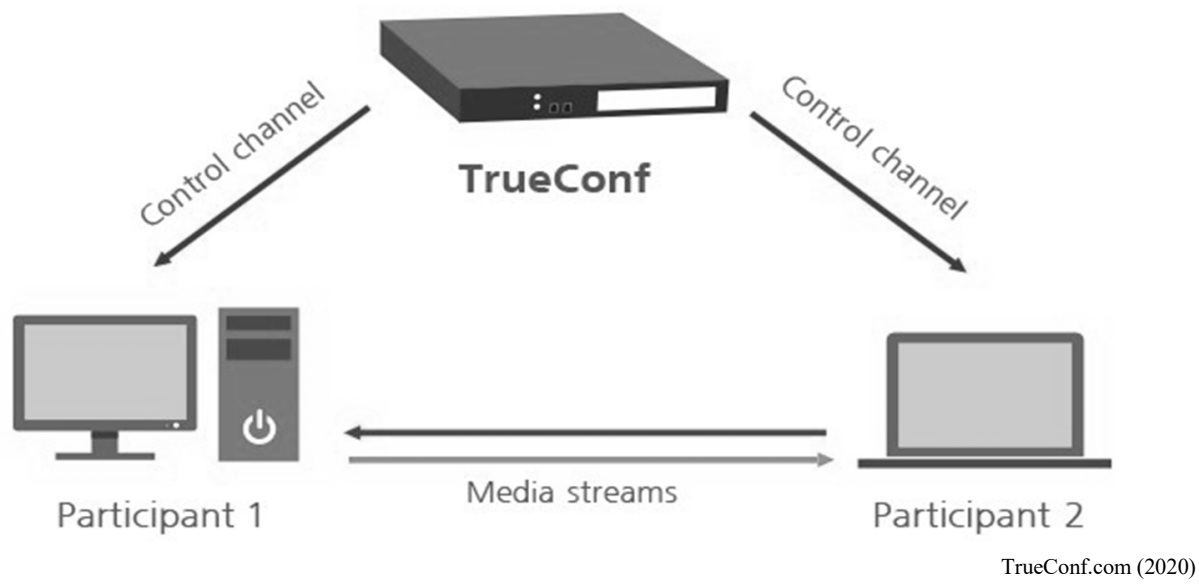

Figure 3. Video Conference Point to Point 


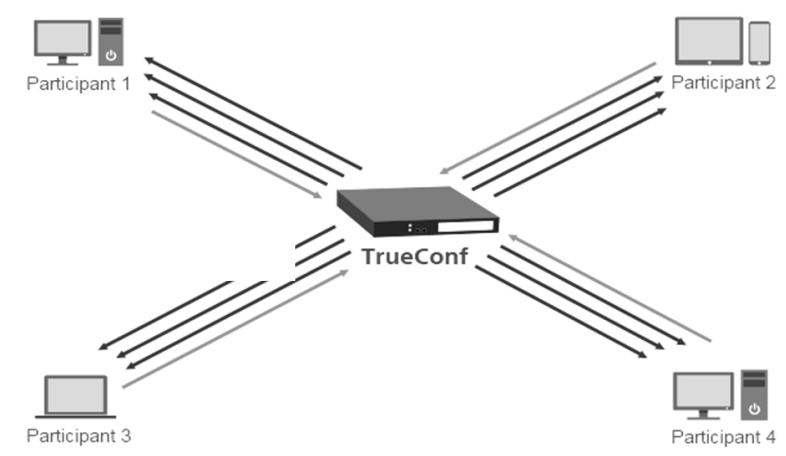

TrueConf.com (2020)

Figure 4. Symmetric Video Conference

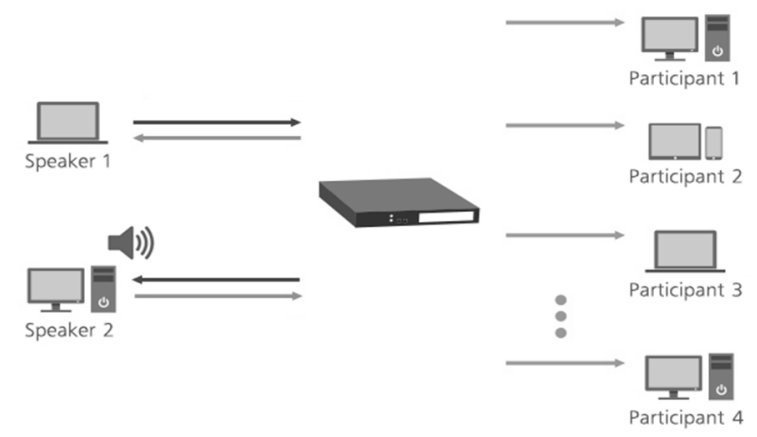

TrueConf.com (2020)

Figure 5. Voice-Activated Switching

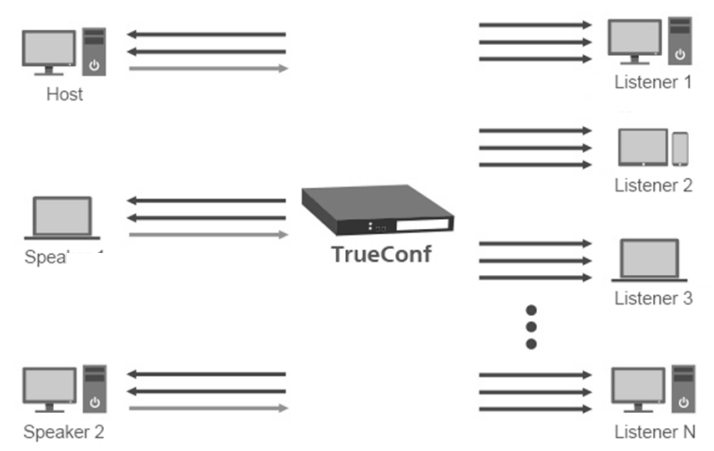

TrueConf.com (2020)

Figure. 6. Role Based Video Conference 


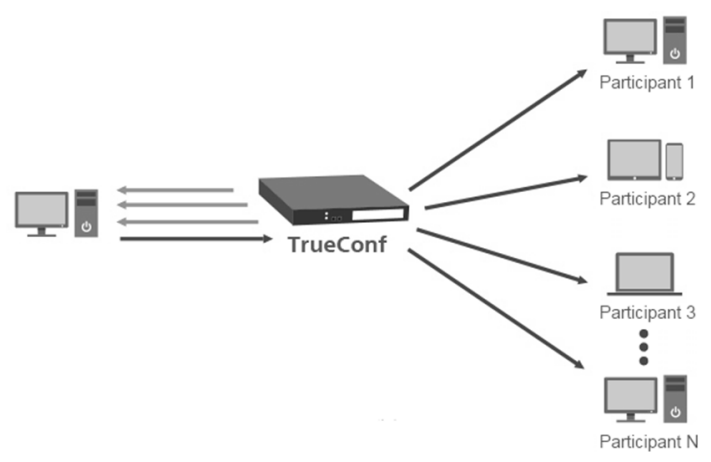

TrueConf.com (2020)

Figure 7. Video Conference for Distance Learning

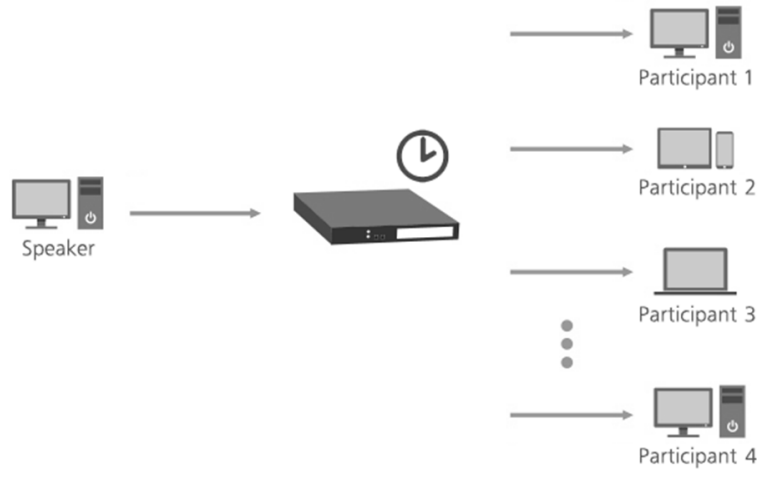

TrueConf.com (2020)

Figure 8. Streaming

Based on the picture above, it explains that there are six strategies that can be carried out by guidance and counseling teachers in making proper collaboration with parents of students in the new normal era. The six strategies have their own strengths and weaknesses. This strategy can be chosen by the teacher by adjusting the conditions, situations or the number of parents who will take part in collaborative activities,

If it is only carried out by the counseling teacher with one parent, it is enough to use the point to point video conference strategy, but if you want a large number, you can used with the strategy of Symmetric Video Conference, Voice-Activated Switching, Role Based Video Conference, Video Conference for Distance Learning and Streaming. Of the six strategies, guidance and counseling teachers can use them by paying attention to the situation, conditions and needs in conducting video conferences.

After the counseling teacher chooses and determines one of the appropriate video conference strategies in collaborating with parents in the new normal era, there are a number of steps that the counseling teacher must understand and follow:

1. The first step for the guidance and counseling teachers must first carry out a trial. This is done to minimize obstacles or technical difficulties in its implementation, make sure the video is displayed properly, hardware or software is functioning properly.

2. The second step for guidance and counseling teachers is to prepare the conference room properly, such as room lighting, microphone or headphones, 
3. The third step, guidance and counseling teachers need to control what they want to capture on the camera such as the background, blackboard or other media to support the background rather than the captured image.

4. The fourth step for the guidance and counseling teacher during the video conference, it is necessary to follow the correct communication ethics, and it is also necessary to convey the rules for activities during the video conference

5. The fifth step The counselor must speak clearly, without shouting, make sure the sound produced is clear and can be understood by the video conference participants

6. The sixth step, BK teachers need to arrange activities or follow-up in an organized manner both before the activity, during the activity or after the video conference activity

7. Seventh step, BK teachers need to have a backup plan, such as rescheduling if there are obstacles during the activity or it is enough to send video recordings at a later time. Conducted so that activities continue and the expected goals can be achieved properly

Here are the principles of partnership during using conferencing video between family with school [30]:

1. Equal rights, equality and mutual appreciate

2. The spirit of mutual cooperation and togetherness

3. Completing and strengthening each other

4. Sharpen each other, love each other, and each other

Considering that collaboration is one of the skills that BK teachers need to have and do in the new normal era, the skills of guidance and counseling teachers in providing guidance and counseling services also need to get full attention from schools as well as the use of video conference media, so that collaboration what is done can be more meaningful [31].

In addition, it requires learning innovations and strategies that must be carried out by educators in order to improve communication, collaboration and interaction between students and teachers in video conferences [32].

\section{Conclusion}

In conclusion, writing research on video conferencing as a counselor collaboration strategy with parents in the new normal era is needed, this is done to build communication, coordination and mutual agreement between counseling teachers in schools and parents in order to achieve the purpose of the guidance and counseling service process in schools can be accomplished well. So that it will have a positive impact in meeting the needs of students at school. This is also to shape the competence and qualifications of counselors in the new normal era, by utilizing this video conference will help and improve the counselors' digital literacy in the current era.

\section{Acknowledgment}

We would like to thank the entire academic community of Ahmad Dahlan University, Yogyakarta and the community of SMAN 1 Cihara, Lebak Regency, Banten Province. Which has provided support morally and materially during the process of writing this paper. 


\section{References}

[1] Nugraha, A., \& Rahman, F. A "Strategi kolaborasi orangtua dengan konselor dalam mengembangkan sukses studi siswa”. Jurnal Konseling Gusjigang, Vol 3 (1), pp 128-136, Juny 2017

[2] Andrew B. Whitford, Soo-Young Lee, Taesik Yun \& Chan Su Jung; "Collaborative Behavior And The Performance Of Government Agencies", International Public Management Journal, Vol 13:4, pp 321-349, 2010

[3] Kelcey, B., \& Phelps, G. "Considerations for designing group randomized trials of professional development with teacher knowledge outcomes". Educational Evaluation and Policy Analysis, Vol 35 (3), pp 370-390. 2013

[4] Worldometers. "Covid-19 Coronavirus Pandemic" from website https://www.worldometers.info/coronavirus/. August 2020

[5] The Lexico Webster Dictionary. USA: The English Language Institue of America. 2020

[6] Susilawati, N. "Tinjauan Yuridis Terhadap Penggunaan Video Teleconference Dalam Rapat Umum Pemegang Saham Terkait Dengan Tugas dan Wewenang Jabatan Notaris". Signifikan, Vol 1 (1), pp 79-88. 2020.

[7] Safa, Najmuddin H. Abd, et al.” مكاسر الدين حسن جامعة في وتطوره بعد عن العربية اللغة تعليم" Nady Al-Adab, Vol 17.1: 29-36. Juny 2020

[8] Sama, H. "Kompetensi Karyawan Dan Efektivitas Penggunaan Video Conference Berbasis Skype Terhadap Efisiensi Waktu Perekrutan Karyawan" CBIS Journal, Vol 2 (2), 2020.

[9] Subekti, H. A., Nubaiti, N., Masilawati, M., \& Fitria, H. "Pemanfaatan Video Conference Sebagai Media Permbelajaran Interaktif Pada Mata Pelajaran Produktif Di Sekolah Menengah Kejuruan”. In Prosiding Seminar Nasional Program Pascasarjana Universitas PGRI Palembang. May, 2020

[10] Abdulsyani, "Sosiologi Skematika, Teori, dan Terapan”, Jakarta: Bumi Aksara, pp 156, 2018.

[11] Hadari Nawawi, “Administrasi Pendidikan”, Jakarta: Gunung Agung, pp 07, 2018

[12] Caraka, P. B., Nindiya, E. S., \& Fuad, A. R. "Improving Quality Of Education Through Collaboration System In The Perspective Of Comprehensive Guidance And Counseling”. pp 1218-1233, 2016

[13] Bhakti, C. P. "Bimbingan dan Konseling Komprehensif: Dari Paradigma Menuju Aksi". Jurnal Fokus Konseling, vol 1 (2), pp 93-106. 2015

[14] Hidayat, Dede Rahmat. "Bimbingan dan Konseling Kesehatan Mental di Sekolah". Bandung: PT Remaja Rosdakarya. 2013

[15]Le, H., Janssen, J., \& Wubbels, T. "Collaborative learning practices: teacher and student perceived obstacles to effective student collaboration”. Cambridge Journal of Education, Vol 48 (1), pp 103-122. 2018

[16]Julian Kitchen, Mandi Berry \& Tom Russell. "The Power of Collaboration”. Studying Teacher Education",Vol 15 (2), pp 93-97, 2019

[17]Butler, E., Prieto, E., Osborn, J. A., Howley, P., Lloyd, A., Kepert, A., \& Roberts, M. "Learning across Discipline Boundaries through Narrative Inquiry: A Study of a Collaboration to Improve Mathematics Teacher Education". Mathematics Teacher Education and Development, Vol 21 (2), pp 87-106. 2019

[18] Noorsyamsa Djumara, "Negosiasi, Kolaborasi dan Jejaring Kerja". Jakarta: Lembaga Administrasi Negara-RI. pp 34-35. 2009 
[19] Yeremias T. Keban, "Pembangunan Birokrasi di Indonesia: Agenda Kenegaraan yang Terabaikan", (Inauguration Speech of Professor at the Faculty of Social and Political Sciences, Gadjah Mada University Yogyakarta, 2007)

[20] Marshal, "Transforming the Way We Work; The Power of Collaborative Workplace”, pp 40, 2010

[21] Tadjudin. "Manajemen Kolaborasi”. Pp 81-82, 2009

[22] Bhaskara, G, I. "Penyiapan Sistem Komunikasi Multimedia Pemerintah Pusat”, Denpasar: Kementerian Agraria dan Tata Ruang/Badan Pertanahan Nasional Ditjen Pengendalian Pemanfaatan Ruang dan Penguasaan Tanah. PT. Ganesha Global Sarana, pp 29, 2017

[23] Menteri Komunikasi dan Informatika Republik Indonesia, "Peraturan Menteri Komunikasi dan Informatika Republik Indonesia Nomor 4 Tahun 2013 Tentang Persyaratan Teknis Perangkat Telekomunikasi Video Conference”, pp 1, 2013

[24] Putra, Yahya Agung; Yahanan, Annalisa; Trisaka, Agus. "Video Konferensi Dalam Rapat Umum Pemegang Saham Berdasarkan Pasal 77 Undang-Undang Perseroan Terbatas". Repertorium: Jurnal Ilmiah Hukum Kenotariatan, pp 8.1: 35-50, 2019

[25] K.V.Rop, "Video Conferencing And Its Application In Distance Learning , University of Eastern Africa, Baraton", Conference: Annual Interdisciplinary Conference, Vol 1 Juni 2012, Nairobi Kenya: The Catholic University of Eastern Africa, pp. 5, 2012

[26] Krutka, D.G, dkk. "Practices and Intercultural Understanding: A Framework for Educator Videoconferencing". Journal of Research on Technology in Education. Vol. 0 (0), 1-20, 2019

[27] Drexhage, J, dkk. "The Connected Classroom: Using Video Conferencing Technology to Enhance Teacher Training”. Reflection Education, Vol 10 (1), pp 70-88, 2016

[28] TrueConf LLC. "What is Video Conferencing? from web https://trueconf.com/what-isvideo-conferencing.html", quoted on 25 August 2020

[29] Al-Samarraie, Hosam. "A scoping review of videoconferencing systems in higher education: Learning paradigms, opportunities, and challenges". International Review of Research in Open and Distributed Learning, 20.3, 2019

[30] Sukiman, Safitrie dkk. "Menjadi Orang Tua Hebat". Jakarta: Kementrian Pendidikan dan kebudayaan. 2016

[31]Bhakti, C. P.; Rahman, F. A. "Android application development of exploration career based on Multiple Intellegence: A model hypothetical". JPhCS, 1470.1: 012043. 2020

[32] Anastasiades, P. S., Filippousis, G., Karvunis, L., Siakas, S., Tomazinakis, A., Giza, P., \& Mastoraki, H. "Interactive Videoconferencing for collaborative learning at a distance in the school of 21 st century: A case study in elementary schools in Greece. Computers \& Education", 54(2), 321-339. 2010 